\title{
EFFECTS OF PARTICLE SIZE OF A POTTER'S "FLINT" AND A FELDSPAR IN WHITEWARE
}

\author{
By R. F. Geller, D. N. Evans, and A. S. Creamer
}

\section{ABSTRACT}

A feldspar and a potter's flint (crushed quartz) of commercial grade were separated by means of an air elutriator into four fractions. Each fraction contained particles grading from the finest originally present to maximum diameters of $10,20,35$, and 75 microns, respectively. In addition, fractions containing particles varying from 35 to 75 microns were separated and a portion of the original feldspar was reground to produce a material composed of particles of 35 micron maximum diameter. The specific surface in $\mathrm{cm}^{2} / \mathrm{g}$ was calculated for each fraction from data obtained by microscopic count.

Various combinations of the several fractions of flint and of feldspar were incorporated in whiteware bodies. Specimens of these bodies were heated at $1150^{\circ}, 1200^{\circ}, 1250^{\circ}, 1300^{\circ}$ and $1350^{\circ} \mathrm{C}$., and tested for linear shrinkage, apparent porosity, strength in bending, and linear thermal expansion. Shrinkage and porosity results were compared with the specific surface values of the flint and feldspar in the respective bodies. Relative fusion and solution in the body was estimated by microscopic examination.

The data obtained indicate the possibility of vitrifying commercial ceramic whiteware with more finely ground materials, and without the use of auxiliary fluxes, at temperatures significantly lower than are now required in the industry.

\section{CONTENTS}

I. Introduction

II. Materials and methods

1. Clays

2. Flint

(a) Chemical purity

(b) Particle-size fractions

(c) Solubility

3. Feldspar

(a) Chemical purity

(b) Particle-size fractions

(c) Solubility

4. Bodies

(a) Compositions

(b) Preparation of specimens

(c) Methods of test..... 332

III. Properties of bodies

1. Shrinkage during drying

2. Shrinkage during heating

3. Apparent porosity after heating

4. Transverse strength

5. Linear thermal expansion

(a) Bodies 1 to 12, inclusive

(1) Specimens heated at $1350^{\circ} \mathrm{C}$

(2) Specimens heated at $1250^{\circ} \mathrm{C}$

(3) Specimens heated at $1150^{\circ} \mathrm{C}_{\ldots} \ldots$

(b) Bodies 18 to 24, inclusive 
III. Properties of bodies-Continued.

6. Fusion and solution

(a) Specimens heated at $1350^{\circ} \mathrm{C}$

(b) Specimens heated at $1250^{\circ} \mathrm{C}$

(c) Specimens heated at $1150^{\circ} \mathrm{C}$

IV. Summary

V. Conclusions

\section{INTRODUCTION}

Success in the manufacture of ceramic clay ware must depend on forming the desired structure by a process of fusion and solution at elevated temperatures. The rate at which this process will proceed is a function not only of temperature but also of the surface areas of the materials. Therefore a study was undertaken of some effects of variations in particle size and corresponding variations in specific surface (area per unit weight) of potter's "flint" and feldspar. This paper is a report of one phase of the study and is confined to ceramic whiteware bodies in which the mean particle sizes of one "flint" (crushed quartz) and of one feldspar were varied.

Flint and feldspar as supplied to the pottery trade are so finely divided that only a small fraction is retained by the no. 325 sieve. Therefore some equipment other than sieves is necessary, not only for determining particle size distribution but also for separating finer sizes of particles in sufficient quantity to study their effects in specimens comparable with commercial products.

The necessary equipment has been supplied by the development of air elutriators ${ }^{1}$ capable of making separations of particles at diameters as small as $10 \mu,{ }^{2}$ and of producing as much as 250 grams of $<10 \mu$ material in an hour of operating time.

TABLE 1.-Chemical compositions of batch materials and of feldspar particle-size fractions

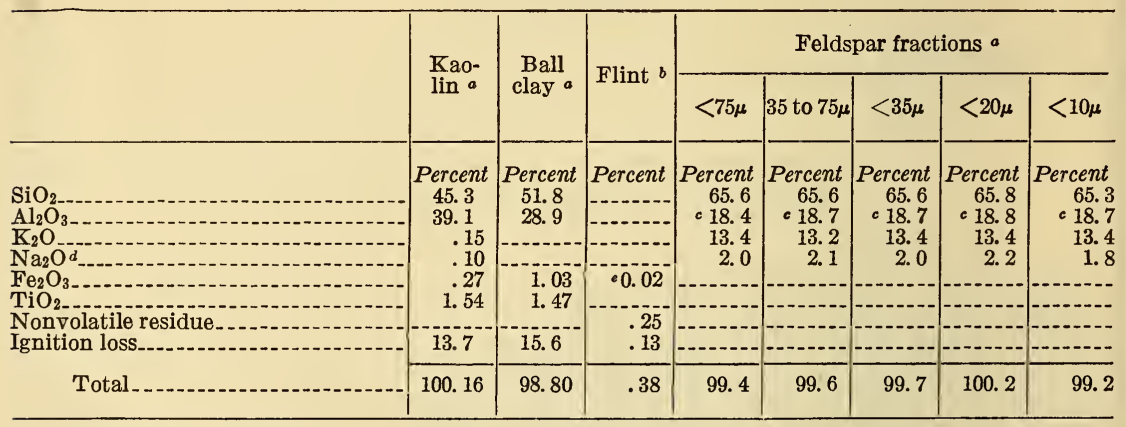

a Analyses by J. F. Klekotka.

$b$ Analysis by F. W. Glaze.

c Determined as $\mathrm{R}_{2} \mathrm{O}_{3}$; includes $\mathrm{Al}_{2} \mathrm{O}_{3}, \mathrm{Fe}_{2} \mathrm{O}_{3}$, TiOn and $\mathrm{P}_{2} \mathrm{O}_{5}$.

$d$ Determined by difference from combined chlorides of $\mathrm{K}$ and $\mathrm{Na}$.

- Included in nonvolatile residue.

1 Constructed by L. A. Wagner of the Bureau of Standards following the principles described by J. C. Pearson and W. H. Sligh in B.S.Tech. Paper No. 48, 1915.

$21 \mu$ (micron) equals $0.0001 \mathrm{~cm}$ or 0.00003937 inch. 


\section{MATERIALS AND METHODS}

\section{CLAYS}

The kaolin (Georgia "soft") and the ball clay (Kentucky No. 4) were washed through a no. 325 sieve, dried, and recrushed to pass a no. 20 sieve. The chemical compositions are given in table 1 .

\section{FLINT}

\section{(a) CHEMICAL PURITY}

The nature and amount of impurities in the flint (Pennsylvania crushed quartz) are given in table 1. The several particle size fractions used in this study were not analyzed chemically because the purity of the original material precluded the possibility of significant variations among them.

\section{(b) PARTICLE-SIZE FRACTIONS}

The several fractions were obtained in the following manner. The original material was first treated in the air elutriator and particles approximately $60 \mu$ and less in maximum diameter were "blown over." The residue was then sieved dry through a no. 325 sieve, ${ }^{3}$ the portion passing the sieve added to the portion blown over by the elutriator, and the combined sample labeled as the " $<75 \mu$ fraction". 4 A portion of this $<75 \mu$ fraction was elutriated further to obtain a fraction composed of particles having diameters between the limits $35 \mu$ and $75 \mu$. Three other portions were elutriated to eliminate particles larger than $35 \mu, 20 \mu$, and $10 \mu$ diameters, respectively. The particle diameter distribution of the $<75 \mu$ fraction with respect to total surface area is shown in figure 1. In table 2 are given the particle diameter distribution by weight, and the calculated values for average diameter " $D$ ", equaling $\Sigma n d^{3}$ divided by $\Sigma n d^{2}$, , and specific surface $\pi n D^{2}$, in $\mathrm{cm}^{2}$ per $\mathrm{g}$, of each fraction. In these calculations, which are based on the assumption that all particles are spheres, " $n$ " equals the total number of particles of any given estimated diameter " $d$ " as determined by microscopic count.

(c) SOLUBILITY

Portions of the $35 \mu$ to $75 \mu$ and the $<10 \mu$ fractions were agitated with distilled water for 48 hours and permitted to settle from suspension for 24 hours. The suspensions were then filtered through especially made filters of $\mathrm{Al}_{2} \mathrm{O}_{3}$ and evaporated to dryness. There was no weighable residue from $200 \mathrm{ml}$ of filtrate from the $35 \mu$ to $75 \mu$ suspension, but the residue from the $<10 \mu$ suspension filtrate indicated a "solubility" of $0.022 \mathrm{~g} / \mathrm{l}$. All of the residue was not in true solution, but examination with the ultramicroscope showed the amount of suspended material to be extremely small. This residue appeared to contain no silica since treatment with $\mathrm{HF}$ produced no significant reduction in weight.

${ }^{3}$ Although the openings of the U.S. Standard no. 325 sieve are theoretically $44 \mu \pm 2.72 \mu$, they will pass particles of crushed quartz or feldspar (normally very irregular in shape) having maximum dimensions of as much as $75 \mu$. The preliminary separation of particles less than $60 \mu$ in diameter, by means of the air elutriator, expedited the sieving operation appreciably.

The portion retained by the sieve, which constituted not more than 5 percent of the initial sample, was discarded.

5 Theodore Hatch, Jour. Franklin Inst., 215 (1), p. 27 (Jan. 1933). 
TABLE 2.-Calculated average diameter and specific surface of fint and feldspar particle size fractions, and particle diameter distribution by weight and by area

\begin{tabular}{|c|c|c|c|c|c|c|c|c|c|}
\hline \multirow{3}{*}{$\begin{array}{l}\text { Nominal } \\
\text { diameter } \\
\text { limits of } \\
\text { fraction }\end{array}$} & \multicolumn{3}{|c|}{ Diameter } & \multicolumn{2}{|c|}{$\begin{array}{l}\text { Specific surface of } \\
\text { fraction } c \text { in } \mathrm{cm}^{2} / \mathrm{g}\end{array}$} & \multicolumn{4}{|c|}{$\begin{array}{l}\text { Particle diameter distribution. } \\
\text { Percentage of initial sample }\end{array}$} \\
\hline & \multirow{2}{*}{$\operatorname{Max} a$} & \multicolumn{2}{|c|}{ Av. $(D)=\frac{\Sigma n d^{3}}{\Sigma n d^{2}}$} & \multirow{2}{*}{ Flint } & \multirow{2}{*}{ Feldspar } & \multicolumn{2}{|c|}{ By weight $b$} & \multicolumn{2}{|c|}{ By area $c$} \\
\hline & & Flint & Feldspar & & & Flint & Feldspar & Flint & Feldspar \\
\hline $\mathrm{S}^{d}{ }^{\mu}{ }^{\mu}$ & ${ }_{35}^{\mu}$ & $\mu$ & $\begin{array}{l}\mu \\
4.8\end{array}$ & $c m^{2}$ & $\begin{array}{c}c m^{2} \\
4,800\end{array}$ & Percent & Percent & Percent & Percent \\
\hline $\begin{array}{l}<10 \\
<20 \\
<35 \\
35 \text { to } 75 .\end{array}$ & $\begin{array}{l}12 \\
30 \\
40 \\
80 \\
80\end{array}$ & $\begin{array}{l}4.6 \\
7.0 \\
11 \\
14 \\
51\end{array}$ & $\begin{array}{l}3.1 \\
6.7 \\
14 \\
15 \\
50\end{array}$ & $\begin{array}{r}5,000 \\
3,200 \\
2,200 \\
1,660 \\
450\end{array}$ & $\begin{array}{r}7,500 \\
3,500 \\
1,850 \\
1,450 \\
470\end{array}$ & $\begin{array}{l}25 \\
45 \\
80 \\
95 \\
15\end{array}$ & $\begin{array}{l}20 \\
40 \\
80 \\
95 \\
15\end{array}$ & $\begin{array}{r}63 \\
80 \\
92 \\
98 \\
7\end{array}$ & $\begin{array}{r}58 \\
78 \\
87 \\
96 \\
9\end{array}$ \\
\hline
\end{tabular}

a Particles having diameters greater than the "nominal" maximum diameter did not, for any fraction exceed 5 percent by weight of the total. This applies to both flint and feldspar.

$b$ Based on separations by air elutriation.

c Calculated from microscopic count.

d Portion of original sample which was reground.

\section{FELDSPAR}

\section{(a) CHEMICAL PURITY}

A feldspar of highest purity was selected from those commercially available ${ }^{6}$ because impurities may segregate in certain of the particle-

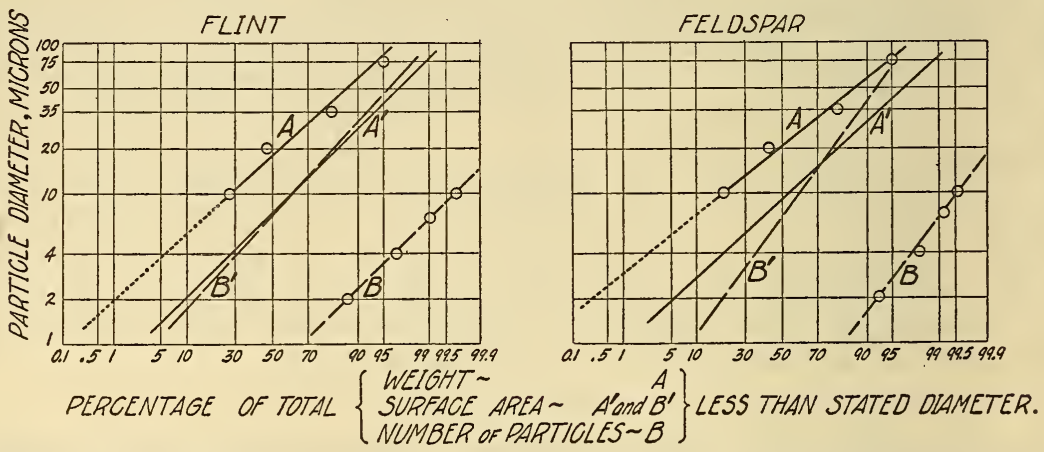

FIGURE 1.-Logarithmic probability curves showing the calculated particle diameter distributions with respect to total surface area (curves $A^{\prime}$ and $B^{\prime}$ ) for the $<75 \mu$ fractions of fint and feldspar which are practically equivalent to the intial samples.

Curves $A^{\prime}$ are calculated from curves $A$ which show the particle diameter distributions with respect to total weight as obtained by air elutriator separation. Curves $B^{\prime}$ are calculated from curves $B$ which show the particle diameter distribution with respect to total number of particles as obtained by microscopic count. Thus, feldspar particles $4 \mu$ and less in diameter constituted approximately 3 percent of the total sample by weight, 18 percent by area as calculated from curve $A, 37$ percent by area as calculated from curve $B$, and 97 percent by microscopic count of particles. For further information on this method of calculating particle distribution see reference in footnote 5 , page 329

size fractions provided they are not in solid solution and are present in appreciable percentages. The chemical composition of each of the fractions used is given in table 1.

\section{(b) PARTICLE-SIZE FRACTIONS}

The fractions (table 1) were obtained in the same manner as described for the flint. In addition, part of the original feldspar

- The material used is from the same source as feldspar no. 19 in the paper by Geller and Creamer in the Jour. Amer. Cer. Soc., vol. 14 (1), p. 30 (Jan. 1931). 
sample (designated in tables 2 and 3 by $S$ ) was ground dry in a ball mill for 34 hours. This grinding reduced the material to particles of less than $35 \mu$ maximum diameter. Particle diameter distribution of the $<75 \mu$ fraction, with respect to total surface area, is shown in figure 1. The average diameter, specific surface, and percentage by weight and area of the initial sample are given, for the respective fractions, in table 2 .

\section{(c) SOLUBILITY}

The "solubility" or, more properly, the relative hydrolysis ${ }^{7}$ of the feldspar was obtained with the same methods as described for the flint. The results, calculated to grams per liter and given to the nearest $0.005 \mathrm{~g}$, are as follows: $35 \mu$ to $75 \mu$ fraction, $0.025 \mathrm{~g}$; $<75 \mu$ fraction, $0.050 \mathrm{~g} ;<35 \mu$ fraction, $0.050 \mathrm{~g} ;<20 \mu$ fraction, $0.065 \mathrm{~g}$; $S$ (reground), $0.070 \mathrm{~g} ;<10 \mu$ fraction, $0.120 \mathrm{~g}$. In the case of the feldspar, as of the flint, examination with the ultramicroscope showed that only an extremely small amount of material in the filtrate was present in suspension. ${ }^{8}$ The following chemical composition was determined for residue from the hydrolysis of the $\langle 10 \mu$ fraction: silica, 19.5 percent; $\mathrm{Al}_{2} \mathrm{O}_{3}$ and $\mathrm{MgO}$, not detectable; $\mathrm{Ca}(\mathrm{OH})_{2}$, 4.4 percent; $\mathrm{NaOH}$ and $\mathrm{KOH}$ (by difference), 76.1 percent.

TABLE 3.-Batch compositions of bodies and particle size fractions of fint and feldspar used in each body

[Nominal diameter limits of feldspar and fint particles ${ }^{1]}$

\begin{tabular}{|c|c|c|c|c|c|c|c|c|c|c|c|c|c|c|c|}
\hline Body no & 1 & 2 & 3 & 4 & 5 & 6 & 7 & 8 & 9 & 10 & 11 & 12 & 18 & 21 & 23 \\
\hline \multirow[t]{2}{*}{$\begin{array}{l}\text { Flint } \\
\text { Feldspar.......... }\end{array}$} & $\begin{array}{l}\mu \\
10 \\
75 \\
\end{array}$ & $\begin{array}{l}\mu \\
20 \\
75\end{array}$ & $\begin{array}{l}\mu \\
35 \\
75\end{array}$ & $\begin{array}{l}\mu \\
75 \\
75\end{array}$ & $\begin{array}{l}\mu \\
75 \\
10\end{array}$ & $\begin{array}{l}\mu \\
75 \\
20\end{array}$ & $\begin{array}{l}\mu \\
75 \\
35\end{array}$ & $\begin{array}{l}\mu \\
10 \\
10\end{array}$ & $\begin{array}{l}\mu \\
20 \\
20\end{array}$ & $\begin{array}{l}\mu \\
35 \\
35\end{array}$ & $\begin{array}{c}\mu \\
35 \text { to } 75 \\
35 \text { to } 75\end{array}$ & $\begin{array}{l}\mu \\
75 \\
S^{2}\end{array}$ & $\begin{array}{lc}\mu & \mu \\
10 & 35 \text { to } 75 \\
10 & 10\end{array}$ & $\begin{array}{cc}\mu & \mu \\
10 & 35 \text { to } 75 \\
\text { (Ball clay) }\end{array}$ & 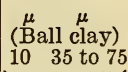 \\
\hline & \multicolumn{12}{|c|}{$\begin{array}{l}\text { Batch compositions: } \\
15 \text { percent ball clay. } \\
35 \text { percent kaolin. } \\
35 \text { percent flint. } \\
15 \text { percent feldspar. }\end{array}$} & $\begin{array}{l}50 \text { percent } \\
\text { flint. } \\
50 \text { percent } \\
\text { feldspar. }\end{array}$ & $\begin{array}{l}50 \text { percent } \\
\text { flint. } \\
50 \text { percent } \\
\text { ball clay. }\end{array}$ & $\begin{array}{l}50 \text { percent } \\
\text { feldspar. } \\
50 \text { percent } \\
\text { ball clay. }\end{array}$ \\
\hline
\end{tabular}

1 Values in the table designate the nominal diameter limits of each fraction. For further details see table 2 .

2 Portion of original sample which was reground.

\section{BODIES}

(a) COMPOSITIONS

The body compositions are given in table 3 .

The mixtures of clay, flint, and feldspar designated as bodies 1 to 12 , inclusive, approximate an average between American earthenware and hotel china compositions. Bodies 18 to 24, inclusive, were subsequently prepared to find additional data bearing on the differences in thermal expansion of bodies 8 and 11 heated to $1,150^{\circ} \mathrm{C}$.

\section{(b) PREPARATION OF SPECIMENS}

Specimens of bodies 1 to 12 , inclusive, were prepared by wetmixing the ingredients for approximately 4 hours and 20 minutes (18,000 revolutions) in a ball mill, using no stones. The resultant "slips" were passed over a magnetic separator, through a no. 80

7 The term "hydrolysis", as applied to feldspar, is suggested by H. G. Byers (unpublished data); Bur. Chem. and Soils, U.S.Dept.Agr.

${ }_{8}$ For more extensive data on the leaching of silica and feldspar by water, and by acid and salt solutions, see Cushman and Hubbard, U.S. Dept. Agr. Bull. 28 (1907), Lenher and Truog, J.Amer.Chem, Soc. 38, 1058 (1916), and Joseph and Hancock, J.Chem.Soc. (Brit,) 123, 2022 (1923). 
sieve, and dried on plaster to a plastic consistency. These plastic masses ${ }^{9}$ were aged in a damp closet for 1 week, then hand kneaded and extruded as rods one half inch in diameter and 6 inches long. A sufficient number of rods were prepared to permit determinations of shrinkage, water absorptivity, and strength on from 10 to 12 specimens of each body from each heat treatment. In addition, specimens for thermal-expansion determinations were molded in the form of disks about $2 \mathrm{~cm}$ in diameter, $0.3 \mathrm{~cm}$ in thickness, with a hole through the center about $0.7 \mathrm{~cm}$ in diameter; and having three small equally spaced cones or "feet" protruding from each side. The average height varied between 0.50 and $0.75 \mathrm{~cm}$. Specimens of each body were heated in a laboratory kiln, using gas as fuel, at five different temperatures, namely, $1,150^{\circ}, 1,200^{\circ}, 1,250^{\circ}, 1,300^{\circ}$, and $1,350^{\circ} \mathrm{C}$. For the final $200^{\circ}$ the temperature was raised at the rate of $20^{\circ}$ per hour and the maximum temperature was maintained for 45 minutes.

The only specimens prepared of bodies 18 to 24 , inclusive, were discs for thermal expansion determinations. Since bodies 18 and 20 (flint-feldspar mixtures) were not self-bonding, gum tragacanth was used as a binder. All of these bodies were heated for 1 hour at $1,150^{\circ} \mathrm{C}$. in an electrically heated furnace.

(c) METHODS OF TEST

The linear shrinkage was determined by measuring the distance, after drying and after heating, between two gage marks which had been pressed $100 \mathrm{~mm}$ apart into the freshly extruded rods. Percentage values are based on the original distance between gage marks.

The water absorptivity, or apparent porosity, of the rods after heating was calculated from the dry weight, the weight after saturating by immersing in water and "autoclaving" for 5 hours at a steam pressure of $150 \mathrm{lb}$./in. ${ }^{2}$, and the bulk volume. The bulk volume was calculated from the weight in air and the weight when suspended in mercury.

To determine the transverse strength a span of 4 inches was used for all of the no. 1 bodies, and for all of the no. 8 bodies except those heated to $1,150^{\circ} \mathrm{C}$. A span of $4 \frac{11}{2}$ inches was used for all others. The load was applied at midspan and the strengths calculated in terms of modulus of rupture.

Thermal expansions were determined by the interferometer method,,$^{10}$ using a heating rate of $2^{\circ}$ to $3^{\circ} \mathrm{C}$. per minute.

The relative fusion and solution which had taken place in the body structures after the several heat treatments was estimated by miscroscopic examinations of thin sections.

- In order to produce optimum workability of each body (nos. 1 to 12 , inclusive) it was necessary to vary the water content, known also as the "tempering water", from 20 percent in body 11 to 34 percent in body 8 . At best, bodies 1, 2, 8, and 9 were very difficult to knead and extrude while bodies 5 and 6 appeared but slightly better. Careful comparisons of the workability of bodies 18 to 24, inclusive, were not made. The general observation that workability is decreased by using very fine fractions of flint and feldspar applied to all of the bodies.

10 G. E. Merritt, B.S. Research Paper No. 515, 1933. 


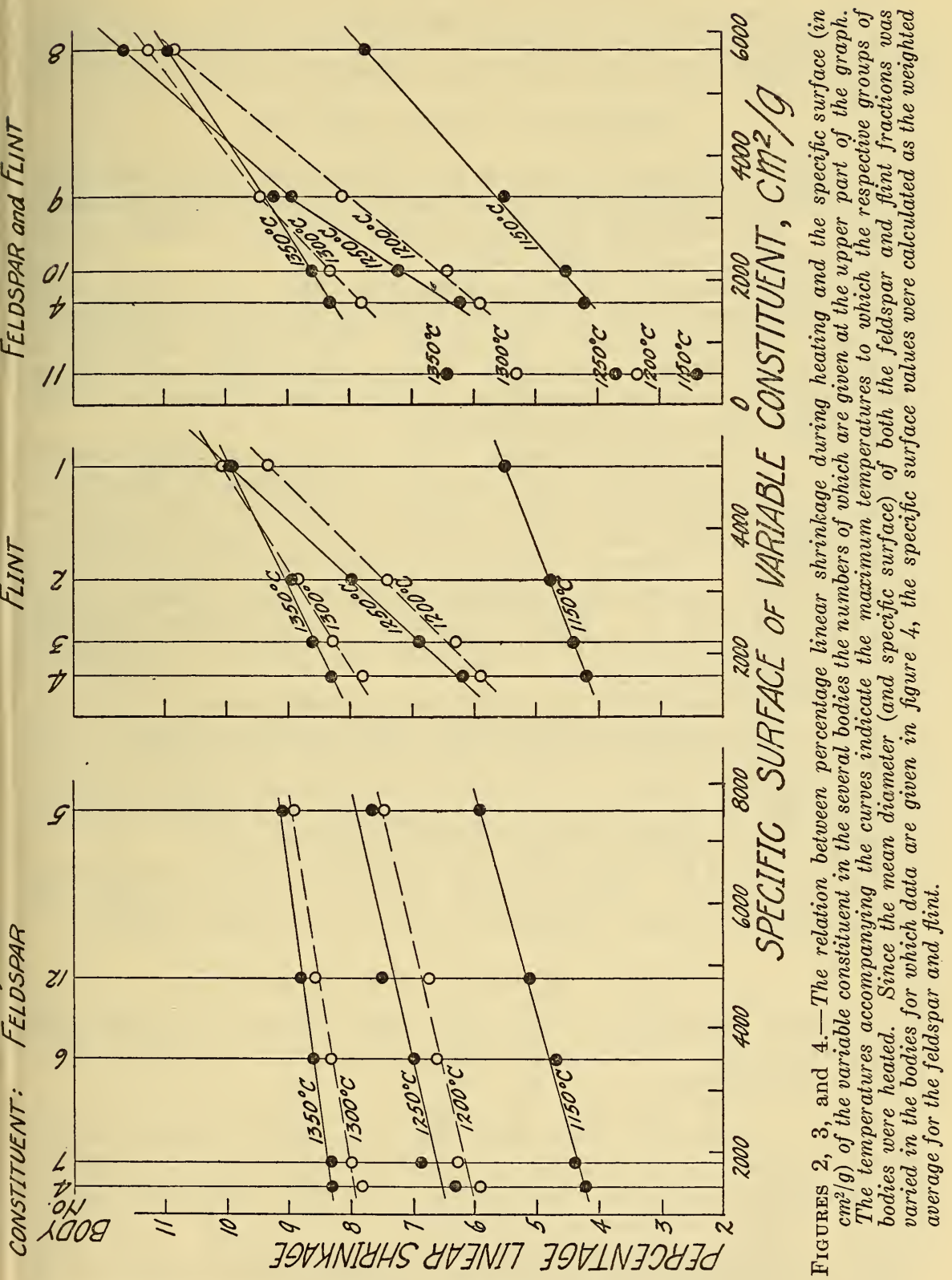




\section{PROPERTIES OF BODIES}

\section{SHRINKAGE DURING DRYING}

The average linear shrinkage during drying for bodies 1 to 12 , inclusive, varied from 2.4 to 3.3 percent. There was no apparent relation between drying shrinkage and other determined properties of the bodies.

\section{SHRINKAGE DURING HEATING}

The shrinkage during heating is the difference in length before and after the specimens were heated and does not include shrinkage during drying. The results are plotted in figures 2,3 , and 4 , which should be studied in connection with table 3 .

Figure 2. Values for all bodies containing the " $<75 \mu$ fraction" of flint are grouped in this figure and specific surface of the feldspar is the only variable in body composition. The greatest difference in shrinkage, at any one temperature, due to variation in specific surface (or particle fineness) of the feldspar (bodies 4 and 5 heated at $1,150^{\circ}$ and $1,200^{\circ}$ C.) is only about $1 \frac{1}{2}$ percent.

Figure 3. The data for bodies $1,2,3$, and 4 , in which specific surface of the flint is the only variable, are plotted in this figure. The increase in shrinkage with increase in specific surface of flint is appreciably greater than with increase in specific surface of feldspar, which effect is in harmony with the fact that the bodies contain 35 percent flint and only 15 percent feldspar. The slightly lower shrinkage of body no. 1 heated at $1,350^{\circ} \mathrm{C}$., as compared with the same body heated at $1,300^{\circ} \mathrm{C}$., indicates that it may be "overfired" at the higher temperature.

Figure 4. Both the flint and feldspar particle fineness was varied in the bodies composing the group for which results are shown in this figure. Bodies 8 and 11, respectively, contain the extremes in particle sizes. Results for body 11 are not strictly comparable with the others because this is the only body containing flint and feldspar particle fractions from which the "fines" had been eliminated.12

Differences in shrinkage of bodies heated at any one temperature are relatively large. The shrinkage of body 8 heated at $1,300^{\circ}$ and $1,350^{\circ} \mathrm{C}$., and of body 9 heated at $1,350^{\circ} \mathrm{C}$., indicates overfiring.

\section{APPARENT POROSITY AFTER HEATING}

Apparent porosities of the bodies after heating are plotted in figures 5,6 , and 7 in which the bodies are grouped as in figures 2,3 , and 4 , respectively.

Figure 5. The differences in apparent porosity corroborate the evidence furnished by shrinkage data (fig. 2) that differences in specific surface of feldspar alone, within the ranges investigated and for bodies containing not more than 15 percent, would not significantly alter the structure of such bodies.

11 That is, a vesicular structure had begun to form which is a condition held to be highly undesirable because of decreased mechanical strength; H. H. Sortwell, Jour. Amer. Cer. Soc. 6 (8) 915 (1923), and R. F. Geller, Bull. Amer. Cer. Soc. 12 (1) 18 (1933).

12 Specific surface increases so rapidly with decreasing particle size, and the finest particles are so difficult to see and to measure, that the calculated specific surface values for the fractions containing "fines" are probably systematically lower than the values for the $35 \mu$ to $75 \mu$ fractions when compared with the respective true values. Such an assumption would account for the fact that results for body 11 (figs. 4 and 7 ) are not in better alignment with results for the other bodies. 

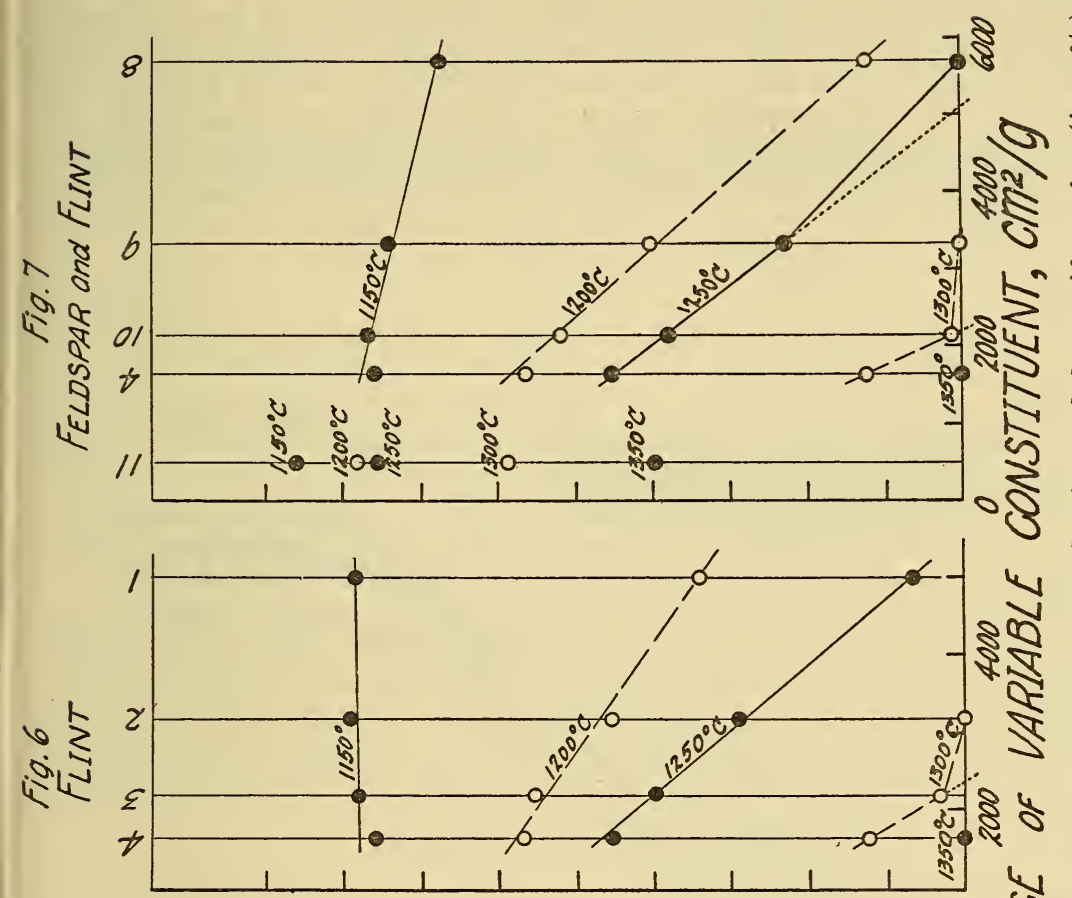

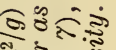

है हूँ

हี हु \&

크을

ปू $\rightarrow$

₹

क क्षे

กั.

कू⿻コ一

क. 요

इ हँ

उٓ

कृष्ठ हैं

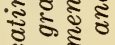
ฐ. సั.

4 इँ हूँ

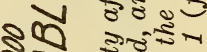
त्ञ⿰冫欠

ปี

잉

ปे ปे०

కิ 200

हु욕-1

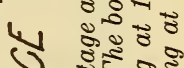
स है. है.

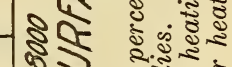

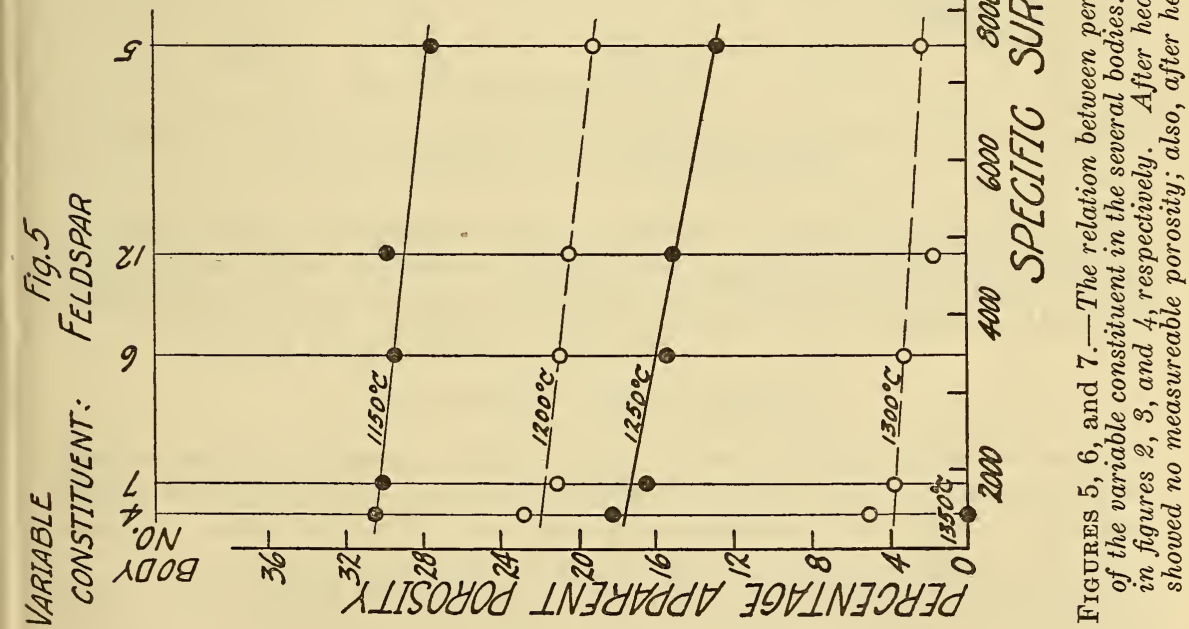


Figure 6. This group of bodies, in which specific surface of the flint is the only variable, shows interesting differences after having been heated to $1,200^{\circ} \mathrm{C}$. and higher temperatures. At $1,200^{\circ}$ C., for example, the substitution of $<10 \mu$ flint for $<75 \mu$ (or practically commercial) material has dropped the apparent porosity from 23 percent to 14 percent (bodies 1 and 4 ) and at $1,250^{\circ} \mathrm{C}$. body 1 is nearly vitrified, while body 4 shows a water absorptivity of about 18 percent.

Figure 7. It is interesting to note, in connection with this group of bodies, that the effectiveness of finer fractions in promoting vitrification is definitely increased when finer fractions of both flint and feldspar are used.

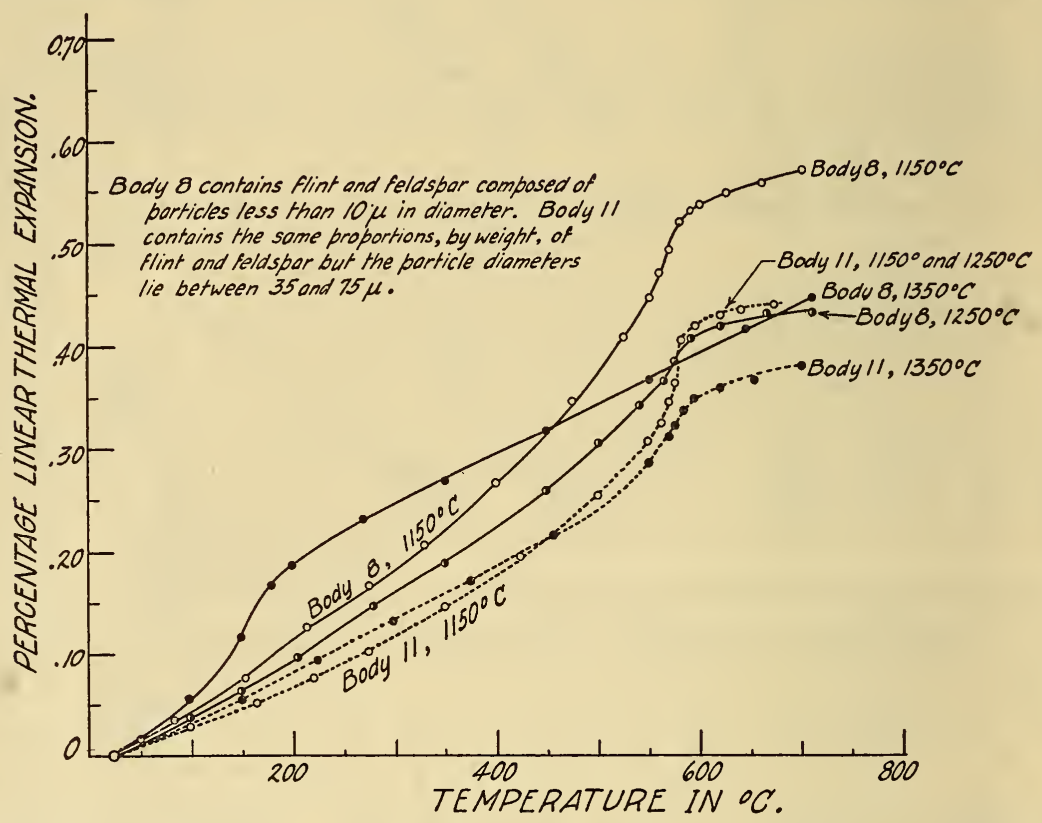

FIgURE 8.-The percentage linear thermal expansion of bodies 8 and 11 heated to the several temperatures indicated.

In general, the data on shrinkage and apparent porosity indicate the possibility of vitrifying commercial whiteware with more finely ground materials, and without the use of auxiliary fluxes, at temperatures significantly lower than are now required in the industry.

\section{TRANSVERSE STRENGTH}

Transverse strengths varied considerably among individual specimens because of the poor workability of many of the plastic bodies and the resultant nonuniformity of the extruded rods. Consequently, detailed results of the tests are not presented.

The average modulus of rupture of body 8 was $5,600 \mathrm{lb} . / \mathrm{in} .^{2}$ after heating at $1,150^{\circ}$ C., $10,000 \mathrm{lb} . / 2 .^{2}$ after heating at $1,250^{\circ}$ C., and $10,800 \mathrm{lb}$./in. ${ }^{2}$ after heating at $1,350^{\circ} \mathrm{C}$. Equivalent values for body 11 were $1,900,2,300$, and $4,300 \mathrm{lb} . / \mathrm{in}^{2}$, respectively. These values represent the extremes. 


\section{LINEAR THERMAL EXPANSION}

(a) BODIES 1 TO 12, INCLUSIVE

The only specimens of bodies 1 to 12 tested were those of bodies 8 and 11 which contain the fractions of highest and lowest specific surface. It was assumed that these two bodies would show, also, the extremes in thermal expansion. The results are shown graphically in figure 8.

(1) Specimens heated at $1,350^{\circ}$ C.-The expansion of body 8 indicates that the quartz has been taken into solution or has been converted into another form of $\mathrm{SiO}_{2}$, probably cristobalite. The expansion of body 11 indicates that a small amount of $\mathrm{SiO}_{2}$ is still present as quartz, but does not indicate the presence of cristobalite or tridymite.

(2) Specimens heated at $1,250^{\circ}$ C.-The presence of quartz, but not of either cristobalite or tridymite, is indicated by the expansion values for both body 8 and body 11 . The expansion of body 11 is lower, except in the range $550^{\circ}$ to $600^{\circ} \mathrm{C}$., than that of body 8 , although the expansions in this range indicate a higher content of quartz in the former. This relatively higher expansion of body 8 is more pronounced for specimens heated at $1,150^{\circ} \mathrm{C}$.

(3) Specimens heated at $1,150^{\circ}$ C.-The expansion of body 8 approximates that of commercial earthenware and is considerably higher than any considered so far. The expansion of body 11 for the temperature range $550^{\circ}$ to $600^{\circ} \mathrm{C}$., indicates a higher content of quartz. Nevertheless, the total percentage expansion of body 11 from room temperature to $700^{\circ} \mathrm{C}$, , or, in fact, for any temperature range except $550^{\circ}$ to $600^{\circ} \mathrm{C}$., is lower than that of body 8 .

\section{(b) BODIES 18 TO 24, INCLUSIVE}

The linear thermal expansions of bodies 18 to 24 , inclusive, are shown by the graphs in figure $9 .^{13}$ The differences in expansion of bodies 21 and 22 (composed of equal parts of flint and clay), are of the same relative order as observed for bodies 8 and 11 heated at $1,150^{\circ}$ C. Also, the thermal expansions of bodies 11 and 22 from room temperature to approximately $500^{\circ} \mathrm{C}$. are similar to that of clay alone ${ }^{14}$ and apparently the much higher expansion of the quartz ${ }^{15}$ does not influence the bulk, or over-all expansion of the bodies. ${ }^{16}$ Petrographic examination shows, furthermore, that very little reaction takes place at clay-quartz contacts in bodies heated at temperatures as low as $1,150^{\circ} \mathrm{C}$. These observations, collectively, suggest the following explanation of the differences in expansion of bodies 8 and 11 , as well as of bodies 21 and 22 :

The quartz in bodies 11 and 22 can conceivably be completely dispersed and surrounded by the other ingredients, principally clay. Consequently, when the specimens are cooled in the kiln or furnace, the quartz particles may shrink away from the surrounding mass of the body leaving a space in which these particles are free to expand

\footnotetext{
13 Specimens made of flint and $35 \mu$ to $75 \mu$ feldspar could not be tested because they were too friable. Furthermore, it was reasonably certain that the difference in the degree of fusion between a " $35 \mu$ to $75 \mu$ fraction" of feldspar, and that of a " $<10 \mu$ fraction", heated at $1,150^{\circ} \mathrm{C}$. would not alter the thermal expansion
sufficiently to explain the facts regarding bodies 8 and 11 . See footnote 6 , page 330 .

14 This refers to clay which has not been heated sufficiently to cause formation of mullite and cristobalite. See W. Steger, Ber. d. Deut. Ker. Gesell. 13 (9) 412, 1932, and R. A. Heindl, B.S.Jour. Research, vol. 8 (RP410), p. 199, 1932.

15 R. B. Sosman, The Properties of Silica, p. 363, The Chem. Cat. Co., 1927.

16 A similar phenomenon has been observed in connection with clay refractories, J. B. Austin and R. H. H.

Pierce, Jr., Jour. Amer. Cer. Soc. 16 (2) 104 (1933).
} 
and contract to a limited amount and therefore have only a limited influence on the bulk or overall expansion. In bodies 8 and 21, however, it is conceivable that the total differential contraction is not sufficient for the quartz to free itself, and therefore the quartz can exert a relatively greater influence on the bulk expansion.

Applying this hypothesis to explain the fact that bodies 18 and 20 have the same expansion curve, it is necessary to assume that the bond between the flint and the feldspar was sufficient to prevent even the large flint particles from freeing themselves in the cooling process.

The curves for bodies 23 and 24 apparently indicate that the presence of flint in the body is necessary to cause the difference in expansion of bodies 8 and 11 .

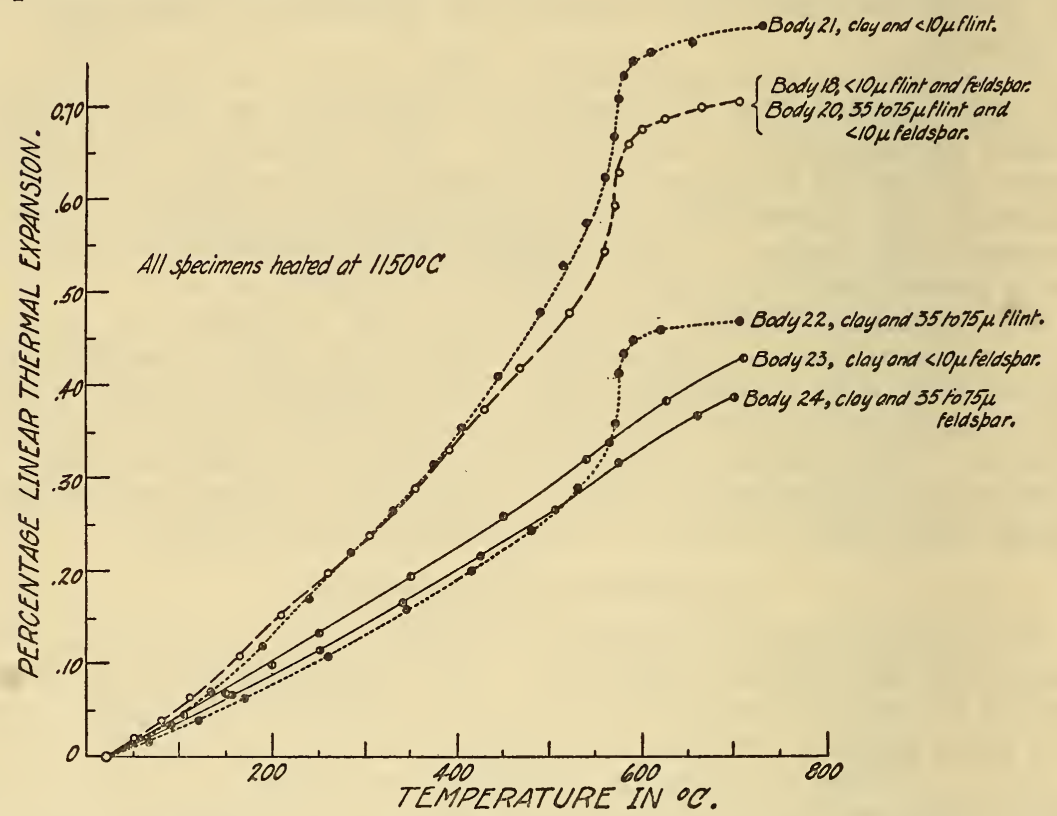

FIgURE 9.-Showing the percentage linear thermal expansion of several bodies heated at $1,150^{\circ}$ C. and containing 50 percent each of clay and fint, flint and feldspar, or clay and feldspar. This group of bodies was tested to obtain further information on the cause of the differences in expansion of bodies 8 and 11 heated to $1,150^{\circ}$ C. (fig. 8).

\section{FUSION AND SOLUTION}

(a) SPECIMENS HEATED AT $1,350^{\circ} \mathrm{C}$.

All of the $<10 \mu$, and nearly all of the $<20 \mu$, feldspar had become diffused through the body. Larger particles of feldspar had lost their sharp outline and were mottled in appearance, indicating the presence of mullite.

A small quantity of the finest particles of quartz (about 10 percent of the body) could be seen in body 8 , although the thermal expansion data did not indicate its presence. Larger particles showed wide solution rims of low index of refraction.

It could be seen plainly that development of mullite had taken place in larger clay particles. 
(b) SPECIMENS HEATED AT $1,250^{\circ} \mathrm{C}$.

No grains of feldspar could be detected in bodies containing the $<10 \mu$ fraction, but a considerable number were distinguishable in bodies containing the $<20 \mu$ fraction. Larger particles showed fairly sharp outlines. The mottled appearance was distinct in portions of $35 \mu$ to $75 \mu$ particles and was quite uniform in particles of less than $35 \mu$ diameter.

The larger quartz particles showed very narrow solution rims, and appreciably less of the very finest particle fraction had dissolved as compared with specimens heated at $1,350^{\circ} \mathrm{C}$.

(c) SPECIMENS HEATED AT $1,150^{\circ} \mathrm{C}$.

Even the coarsest particles of feldspar, although completely fused to glass, maintained sharp outlines; the finest $(<10 \mu)$ particles could be detected in considerable quantities. None of the quartz particles of sufficient size to be identified showed solution rims and probably not more than 10 percent of the $<10 \mu$ fraction (body 8) had dissolved.

\section{SUMMARY}

A feldspar and a potter's flint (crushed quartz) of commercial grade were separated by means of an air elutriator into fractions, and in addition a portion of the original feldspar was reground.

The calculated specific surface, based on data obtained by microscopic count, varies from $450 \mathrm{~cm}^{2} / \mathrm{g}$ for the 35 to 75 micron flint fraction to $7,500 \mathrm{~cm}^{2} / \mathrm{g}$ for the less than 10 micron feldspar fraction. The relative solubility of even the finest particle-size fractions of flint is probably negligible $(0.04 \mathrm{~g}$ per liter) while the solubility of the feldspar varied from $0.025 \mathrm{~g}$ per liter for the 35 to 75 micron fraction to $0.120 \mathrm{~g}$ per liter for the finest fraction.

In general, the workability is decreased by using the very fine fractions of flint and of feldspar. There is comparatively little difference in linear shrinkage during drying; the extremes were 2.4 and 3.3 percent.

Varying the specific surface of feldspar only, does not greatly affect the shrinkage during heating at any one temperature; the maximum increase was from 5.9 percent to 7.5 percent. The effect on apparent porosity is also relatively small; the maximum reduction was from 18.4 percent to 13 percent. This indicates, for a body containing only 15 percent feldspar, that feldspar of less than 10 microns diameter can be substituted for one of the same chemical composition but of average present-day commercial fineness without greatly altering the ultimate structure of the body. The effects of varying the mean particle size, or specific surface, of flint only is more pronounced; the maxima were from 6.4 percent to 10 percent increase in linear shrinkage and from 18.5 percent to 2.8 percent reduction in apparent porosity. The greater effectiveness of the flint is in harmony with the fact that the bodies contain 35 percent flint and only 15 percent feldspar. Using increasingly finer fractions of both flint and feldspar produced a maximum increase in shrinkage from 6 percent to 11.6 percent and a maximum reduction in porosity from 18 percent to zero percent.

Transverse strengths varied between the extreme modulus of rupture values of 5,600 and $1,900 \mathrm{lb}$./in. ${ }^{2}$ respectively for bodies heated $4551-33-3$ 
at $1,150^{\circ} \mathrm{C}$., and 10,800 and $4,300 \mathrm{lb} . / \mathrm{in} .^{2}$ for the same bodies heated at $1,350^{\circ} \mathrm{C}$.

Linear thermal-expansion determinations warrant the generalization that thermal expansion may be influenced greatly by extremes in particle size of flint and feldspar. The use of flint containing no particles of less than 35 microns diameter may produce bodies of unusually low expansion when compared with bodies of similar composition but containing much finer flint.

The effects of particle-size variations on relative fusion and solution in the body structures were well defined when observed microscopically.

\section{CONCLUSIONS}

The data obtained indicate the possibility of vitrifying commercial ceramic whiteware with more finely ground materials, and without the use of auxiliary fluxes, at temperatures significantly lower than are now required in the industry. Further studies of the effects of particle sizes of flint and feldspar in ceramic whiteware bodies, particularly with regard to the development of bodies which can be used advantageously on a commercial scale, are believed justified.

WAshington, July 24, 1933. 